\title{
TERAPI SIKLOFOSPAMID PADA PASIEN ANEMIA APLASTIK DI RSHAM
}

\author{
Julahir H.Siregar \\ Staf pengajar Fakultas Kedokteran \\ Universitas Islam Sumatera Utara \\ eMail: julhirsrg@uisu.ac.id
}

\begin{abstract}
Aplastic anemia is a disorder of the clinical syndrome which is characterized by red blood cell deficiency, neutrophils, monocytes and platelets without any other form of marrow damage. Patients in the study included poly hematologic oncology patients and RSHAM inpatients who had been diagnosed with aplastic anemia and had 4 cycles of chemotherapy with cycloposfamide. Data was collected retrospectively, which included: personal data, how many cycles followed cycloposphamide therapy, hemoglobin, leukocytes, platelets before and after chemotherapy and how many PRCS and platelets were given. In this study involved too few patients and most patients were not tested for bone marrow examinations for evaluation. Before cycloposfamide therapy is given a cytogenetic examination is not performed. From the data above, we cannot conclude whether cycloposfamide therapy given in RSHAM gives a good response or not.
\end{abstract}

\section{Keywords: Anemia Aplastik, Kemoterapi. Siklofospamid}

\section{PENDAHULUAN}

Anemia aplastik merupakan suatu kelainan dari sindrom klinik yang diantaranya ditandai oleh defisiensi sel darah merah, neutrophils, monosit dan platelet tanpa adanya bentuk kerusakan sumsum lainnya. Dalam pemeriksaan sumsum dinyatakan hampir tidak ada hematopoetik sel perkusi dan digantikan oleh jaringan lemak. Kerusakan ini bisa disebabkan oleh zat kimia beracun, virus tertentu, atau bisa juga karena faktor keturunan.

Insidensi anemia aplastik di eropa dan amerika bagian utara sekitar 2/1.000.000 penduduk pertahun, tetapi di Asia Timur angka tersebut meningkat menjadi sebanyak 2-3 kali dari angka tersebut.

Secara garis besarnya terapi untuk anemia aplastik dapat dibagi menjadi 4 yaitu: terapi kausal; terapi suportif; terapi untuk memperbaiki fungsi sumsum tulang; serta terapi definitif. terapi definitive berupa: terapi imunosupresif (siklosporin, ATG,ALG, sikloposfamide) dan transplantasi sumsum tulang. Pada beberapa center dan beberapa hasil penelitian penggunaan dosis tinggi sikloposfamide memebrikan hasil yang baik terhadap Anemia Aplastik, tetapi pada beberapa hasil penelitian tidak menunjukkan hasil yang memuaskan.Pada laporan ini akan dilaporkan mengenai bagaimana efektivitas sikloposfamide pada pasien Anemia aplastik di RSHAM Medan.

\section{METODE PENELITIAN}

Pengumpulan data dilakukan dengan menggunakan metode retsrospektif. Pasien pada penelitian meliputi pasien poli hematologik onkologi dan pasien rawat inap RSHAM yang telah di diagnosa anemia aplastik yang dibuktikan dengan hasil kesimpulan BMP berupa anemia aplastik, dan sudah menjalani kemoterapi dengan sikloposfamide sebanyak 4 siklus. Jumlah pasien yang memenuhi criteria tersebut sebanyak 6 orang.

Data dikumpulkan secara restrospektif dimana data diambil dari rekam medis pasien yang sudah didiagnosa dengan anemia aplastik, yang meliputi: data pribadi, berapa siklus mengikuti terapi cycloposphamide, haemoglobin, leukosit, trombosit sebelum dan sesudah kemoterapi dan berapa jumlah PRC 
dan Trombosit yang di berikan. Data diolah dan dianalisa dengan uji Wilcoxon menggunakan program SPSS versi 17 dengan batas kemaknaan $p<0,05$.

\section{HASIL}

Hasil laboratorium pada pasien Anemia aplastik yang telah mendapat terapi ciklofospamide ditampilkan pada table 1 . Pada tabel tersebut bias dilihat bagaimana jumlah haemoglobin, leukosit, trombosit baik sebelum dan sesudah tansfusi packed red cell (PRC) dan juga Trombosit. Data pada table tersebut terlihat bahwa pada beberapa pasien menunjukkan hasil yang baik tetapi pada beberapa pasien nampaknya tidak menimbukan efek terapi seperti yang diharapkan.

Tabel 1. Hasil laboratorium sebelum dan sesudah terapi siklofospamid

\begin{tabular}{|c|c|c|c|c|c|c|c|c|c|c|}
\hline \multirow[t]{3}{*}{ No } & \multirow[t]{3}{*}{ Nama } & \multicolumn{9}{|c|}{ Hasil } \\
\hline & & \multirow[b]{2}{*}{ Kemoterapi } & \multicolumn{3}{|c|}{ Pre Sikloposfamid } & \multicolumn{2}{|c|}{ Transfusi } & \multicolumn{3}{|c|}{ Post Sikloposfamid } \\
\hline & & & $\mathrm{Hb}$ & $\begin{array}{l}\text { Leuk } \\
0\end{array}$ & $\begin{array}{l}\text { Trom } \\
\text { b }\end{array}$ & $\begin{array}{l}\mathrm{PR} \\
\mathrm{C}\end{array}$ & $\begin{array}{l}\text { Trom } \\
\text { b }\end{array}$ & $\mathrm{Hb}$ & Leuko & $\begin{array}{l}\text { Trom } \\
\text { b }\end{array}$ \\
\hline \multirow[t]{4}{*}{1} & \multirow{4}{*}{$\begin{array}{l}\text { Gani Tongonda } \\
085261777558 \\
\text { MR: } 61.13 .34\end{array}$} & $\begin{array}{l}\text { K-I } \quad(12-9- \\
14)\end{array}$ & 4.2 & 0.48 & 43 & 5 & - & 9.9 & 1.38 & 67 \\
\hline & & $\begin{array}{l}\text { K-II }(20-10- \\
14)\end{array}$ & 8.4 & 2.28 & 154 & - & - & 9.1 & 7.3 & 163 \\
\hline & & $\begin{array}{l}\text { K-III } \\
11-14)\end{array}$ & $\begin{array}{l}12 . \\
2\end{array}$ & 3.07 & 242 & - & - & 12 & 3 & 178 \\
\hline & & $\begin{array}{l}\text { K-IV (17-12- } \\
14)\end{array}$ & $\begin{array}{l}12 . \\
4\end{array}$ & 16.0 & 121 & - & - & 11.3 & 5.8 & 120 \\
\hline \multirow[t]{4}{*}{2} & $\begin{array}{l}\text { Edison } \\
\text { Aritonang }\end{array}$ & $\begin{array}{l}\text { K-I } \quad(10-12- \\
14)\end{array}$ & 4.7 & 1.42 & 7 & 3 & 5 & 6.5 & 1.3 & 9 \\
\hline & $\begin{array}{l}081362706322 \\
\text { MR : } 61.29 .27\end{array}$ & $\begin{array}{l}\text { K-II （14-1- } \\
15)\end{array}$ & 5.8 & 1.69 & 19 & 3 & 4 & 8.5 & 1.06 & 18 \\
\hline & $\begin{array}{l}\text { Partial respon } \\
\text { Pasien tidak }\end{array}$ & $\begin{array}{l}\text { K-III (24-2- } \\
15)\end{array}$ & 8.3 & 2.8 & 51 & - & - & 8.3 & 2.7 & 50 \\
\hline & $\begin{array}{l}\text { bersedia BMP } \\
\text { ulang }\end{array}$ & $\begin{array}{l}\text { K-IV (24-3- } \\
15)\end{array}$ & 8.9 & 3.06 & 63 & - & - & 8.8 & 2.9 & 64 \\
\hline \multirow[t]{4}{*}{3} & $\begin{array}{l}\text { Nuraini } \\
085260813075\end{array}$ & $\begin{array}{l}\text { K-I } \\
(14 / 5 / 14)\end{array}$ & 7.3 & 1.9 & 6 & 3 & 3 & 9.2 & 2.82 & 11 \\
\hline & 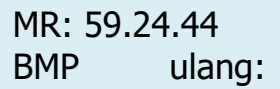 & $\begin{array}{l}\text { K-II } \\
(13 / 6 / 14)\end{array}$ & 4.7 & 2.6 & 25 & 4 & 3 & 10.1 & 1.6 & 40 \\
\hline & $\begin{array}{l}\text { Eritropoietik } \\
\text { hiperaktif }\end{array}$ & $\begin{array}{l}\text { K-III } \\
(14 / 7 / 14)\end{array}$ & 9.4 & 2.6 & 45 & - & - & 9.5 & 2.8 & 43 \\
\hline & & $\begin{array}{l}\text { K-IV } \\
(13 / 8 / 14)\end{array}$ & 9 & 2.8 & 39 & - & - & 9.2 & 1.79 & 43 \\
\hline \multirow[t]{4}{*}{4} & $\begin{array}{l}\text { Painem } \\
\text { MR: 00.02.38 }\end{array}$ & $\begin{array}{l}\text { K-I } \quad(22-12- \\
14)\end{array}$ & 5.2 & 3.0 & 55 & 3 & - & 8.9 & 3.3 & 57 \\
\hline & & $\begin{array}{l}\text { K-II } \\
(22 / 1 / 15)\end{array}$ & 8.1 & 2.0 & 90 & 2 & - & 10.1 & 3.2 & 74 \\
\hline & & $\begin{array}{l}\text { K-III } \\
23 / 2 / 15)\end{array}$ & 6.1 & 3.3 & 47 & 2 & - & 8.6 & 3.7 & 26 \\
\hline & & $\begin{array}{l}\text { K-IV } \\
(23 / 3 / 15)\end{array}$ & 3.7 & 2.5 & 61 & 4 & - & 7.0 & 3.1 & 61 \\
\hline \multirow[t]{3}{*}{5} & Mustika & $\begin{array}{l}\text { K-I } \quad(18-10- \\
14)\end{array}$ & 4.6 & 2.26 & 40 & 3 & 5 & 7 & 4.3 & 45 \\
\hline & $\begin{array}{l}\text { Chandra } \\
60.14 .23\end{array}$ & $\begin{array}{l}\text { K-II } \\
28 / 11 / 14)\end{array}$ & 7.6 & 5.6 & 11 & 2 & 5 & 10.6 & 4.2 & 19 \\
\hline & & $\begin{array}{l}\text { K-III } \\
(29 / 12 / 14)\end{array}$ & 6.5 & 3.4 & 19 & 2 & 5 & 8.8 & 3.6 & 19 \\
\hline
\end{tabular}


6

Ngatiem

MR : 62.48 .59

\section{K-IV}

$(29 / 1 / 15)$

K-I

$(15 / 12 / 14)$

4.6
REVISED: 8 SEPTEMBER \\ ACCEPTED: 09 OKTOBER 2018}

$\begin{array}{llllllllll}\text { K-II } & (14-1- & 13 . & 1.44 & 9 & - & 5 & 12.7 & 1.96 & 33 \\ 15) & 3 & & & & & & & \\ \text { K-III } & (12-2- & 8.6 & 1.77 & 9 & 1 & 5 & 9.1 & 2.6 & 31 \\ \begin{array}{l}15) \\ \text { K-IV }\end{array} & (16-3- & 6.4 & 1.48 & 6 & 3 & 5 & 9.2 & 1.3 & 27 \\ 15) & & & & & & & & & \end{array}$

Tabel. 2. Hemoglobin sebelum dan sesudah kemoterapi.

\begin{tabular}{|cc|c|c|c|}
\hline & & $\mathrm{N}$ & Mean Rank & Sum of Ranks \\
\hline HbPost - HbPre & Negative Ranks & $5^{\mathrm{a}}$ & 7,40 & 37,00 \\
& Positive Ranks & $18^{\mathrm{b}}$ & 13,28 & 239,00 \\
& Ties & $1^{\mathrm{c}}$ & & \\
& Total & 24 & & \\
\hline
\end{tabular}

\begin{tabular}{|c|c|}
\hline & $\begin{array}{c}\text { HbPost - } \\
\text { HbPre }\end{array}$ \\
\hline$Z$ & $-3,072^{\mathrm{b}}$ \\
Asymp. Sig. (2-tailed) &, 002 \\
\hline
\end{tabular}

Tabel.3 Leukosit sebelum dan sesudah kemoterapi.

\begin{tabular}{|cc|c|c|c|}
\hline & & $\mathrm{N}$ & Mean Rank & Sum of Ranks \\
\hline LeukoPost - LeukoPre & Negative Ranks & $11^{\mathrm{a}}$ & 11,50 & 126,50 \\
& Positive Ranks & $13^{\mathrm{b}}$ & 13,35 & 173,50 \\
& Ties & $0^{\mathrm{c}}$ & & \\
& Total & 24 & & \\
\hline
\end{tabular}

\begin{tabular}{|c|c|}
\hline & $\begin{array}{c}\text { LeukoPost - } \\
\text { LeukoPre }\end{array}$ \\
\hline $\mathrm{Z}$ &,$- 672^{\mathrm{b}}$ \\
\hline Asymp. Sig. (2-tailed) &, 502 \\
\hline
\end{tabular}

Tabel.4 Trombosit sebelum dan sesudah kemoterapi.

\begin{tabular}{|cc|c|c|c|}
\hline & & $\mathrm{N}$ & Mean Rank & Sum of Ranks \\
\hline TrombPost - TrombPre & Negative Ranks & $7^{\mathrm{a}}$ & 10,36 & 72,50 \\
& Positive Ranks & $15^{\mathrm{b}}$ & 12,03 & 180,50 \\
& Ties & $2^{\mathrm{c}}$ & & \\
& Total & 24 & & \\
\hline
\end{tabular}

\begin{tabular}{|c|c|}
\hline & $\begin{array}{c}\text { TrombPost - } \\
\text { TrombPre }\end{array}$ \\
\hline Z & $-1,756^{\mathrm{b}}$ \\
& 079 \\
\hline
\end{tabular}

\section{PEMBAHASAN}

Terapi definitif pada anemia aplastik adalah transplantasi sumsum tulang. Untuk 
melakukan terapi transplantasi sumsum tulang tersebut perlu diperhatikan berbagai factor pada pasien tersebut seperti: usia pasien, adanya donor saudara yang cocok (matched sibling donor), faktor resiko infeksi atau beban trasnfusi. Selain dengan terapi tersebut diatas pada pasien anemia aplastik juga dapat diberikan seperti terapi imunosupresi. Salah satu terapi iumosupresi tersebut mencakup terapi dengan sikloposfamid.

Terapi sikloposfamid dosis tinggi (50 $\mathrm{mg} / \mathrm{kg}$ ) telah dianjurkan sebagai lini pertama yang efektif untuk anemia aplastik. 1,8,9 Angka respon yang tinggi dikaitkan dengan pencegahan kekambuhan dan juga penyakit klonal. Namun sitopenia yang berkepanjangan menghasilkan toksisitas yang berlebihan akibat komplikasi neutropenik . Follow-up jangka panjang pada pasien yang mendapat sikloposfamide memperlihatkan bahwa relaps dan penyakit klonal dapat terjadi setelah terapi sikloposfamid.

Pada hasil penelitian ini terlihat tidak sesuai dengan hasil penelitian diatas, pada data table satu diatas kita lihat bahwa pada sebagian besar terapi sikloposfamide yang diberikan tidak memberikan respon seperti yang diharapkan untuk mencapai respon komplit. Secara statistic terlihat hasil yang bermakna pada haemoglobin walaupun pada sebagian pasien tidak erlihat adanya perbaikan. Sebaliknya pada leukosit dan trombosit terlihat hasil yang tidak bermakna secara statistic. Hal yang sama juga bisa kita lihat dari hasil penelitian yang dilakukan oleh Griner. ${ }^{10}$ Hampir pada semua pasien yang diterapi dengan sikloposfamide pada penelitian masih menunjukkan adanya sitopenia dan masih membutuhkan transfusi sel darah merah dan transfuse trombosit. Pada penlitian juga hanya satu pasien yang mau mengikuti untuk pemeriksaan sumsum tulang ulangan sebagai evaluasi dan didapatkan hasil yang bagus dimana tercapai keadaan Eritropoietik hiperaktif. Kurangnya efektivitas dari pemberian sikloposfamid ini masih memungkin dikarenakan adanya delesi pada pasien-pasien yang mendapat terapi yang dikarenakan oleh semua pasien tersebut sebelum mendapat terapi imunosupresan tidak dilakukan pemeriksaan sitogenetik.

\section{KESIMPULAN}

Pada penelitian yang dilakukan ini melibatkan pasien yang terlalu sedikit dan juga sebagian besar pasien tidak dilakukan pemeriksaan sumsum tulang ulangan untuk evaluasi. sbelum terapi sikloposfamide diberikan pemeriksaan sitogenetik tidak dilakukan. Dari data yang ada diatas sebenarnya belum dapat diambil kesimpulan apakah terapi sikloposfamide yang diberikan di RSHAM Medan memebrikan respon yang baik atau tidak. ${ }^{11}$

\section{DAFTAR PUSTAKA}

Alkhouri N, Ericson SG. Aplastic Anemia:Review of Etiology and Treatment. 1999;70:46-52.

Bakta IM. Anemia Karena Kegagalan Sumsum Tulang. In: Hematologi Klinik

Ringkas. Cetakan I. Jakarta: EGC;2006. p. 97-112.

Brodsky RA., Sensenbrenne LL., Jones RJ: Complete Remission in Severe Aplastic Anemia After High-Dose Cyclophosphamide Without Bone Marrow Transplantation; Blood, Vol 87, No 2 (January 151, 1996 pp 491494

DeZern A.E., Guinan E.C; Therapy for Aplastic Anemia; American Society of Hematology:2011: 1-2

DeZern AE., Petri M., Drachman DB: High Dose Cyclophosphamide without Stem Cell Rescue in 207 Patients with Aplastic anemia and other Autoimmune Disease; Medicine (Baltimore). 2011 March ; 90(2): 8998.

Griner PF: A survey of the effectiveness of cyclophosphamide in patients with severe aplastic anemia. Am J Hematol 8:55, 1980

Guinan EC: Diagnosis and Management of Aplastic Anemia; American Society of Hematology

Montane', E., Iba'ñez, L., Vidal, X., Ballarin, E., Pig, R., Garcia, N. \& Laporte, J.R., the Catalan Group for the Study of Agranulocytosis and Aplastic Anemia (2008) Epidemiology of aplastic anemia: a prospective multicenter study. Haematologica 93, 518-523. 
Marsh J.C.W, Ball s.E,Cavenagh j. et all: Guidelines for the diagnosis and management of aplastic anaemia; British Journal of Haematology :2009; 147, 43-70
Widjanarko A., Sudoyo AW., Salonder H. Anemia aplastik . dalam Buku Ilmu penyakit dalam jilid II edisi VI.

Shadduck RK. Aplastic Anemia. In: Beuttler E, Coller BS, Lichtman M, Kipps TJ.

Williams Hematology. 6th ed. USA: McGraw-Hill;2001. p. 504-523. 